It will be recalled that, in Greek legend, Procrustes made all travellers who visited him lie on a bed of fixed length, stretching their limbs if they were too short and lopping them off if they were too long. Mr. Knox suggested that this treatment, although murderous when applied to human beings, is beneficial when applied to problems. It is a great advantage to make a wide range of problems conform to one fixed type, namely, that usually known as the method of ratio or proportion. Examples were given of applications to arithmetic, algebra, geometry and applied mathematics.

\section{Books on the History of Science and Medicine}

Catalogue 55, recently issued by E. P. Goldschmidt and Co., 45 Old Bond Street, W.1, is devoted to bibliography and reference books, particularly those dealing with the history of science and medicine. Attention may be directed to the following items: A. Claudius's "Histoire de l'imprimerie en France" (1900-1914), Du Cange's "Glossarium mediæ et infimæ Latinitatis" (1883-1887), Thomas James's "Catalogue of the Bodleian Library" (1620-1635), J. S. Bailly's "Histoire de l'Astronomie ancienneHistoire de l'Astronomie moderne-Traité de l'astronomie Indienne et Orientale"' (1.781-1787), L. Choulant's "Handbuch der Bücherkunde für die aeltere Medizin" (1828), John Ferguson's "Bibliographical Notes of Histories of Inventions and Books of Secrets" (1883-1916), John Leland's "Laboryouse Journey and Serche for Englandes Antiquitees" (1549), and Andrew Borde's 'Fyrst Boke of the Introduction of Knowledge" (1548).

\section{Aftershocks of the Great Turkish Earthquake}

As anticipated by the seismologists at the Istanbul Observatory, aftershocks of the great Turkish earthquake of December 27 (NATURE, January 6, p. 13) still continue, and these have been accompanied by floods possibly due to changes of land-level occasioned by the shocks. The region most affected recently has been near the scene of the original disaster. On April 3, two violent earthquake shocks occurred in the region of Amasya in Anatolia. No casualties are reported. Following torrential rains, the Yesil Irmak and the Tersakar Dere burst their banks, flooding wide areas, including the famous apple orchards near Amasya, and also inundating about thirty villages, some of which have had to be abandoned. Twenty. five villages were cut off by the floods. No casualties have been reported.

\section{Cerebro-Spinal Fever}

Cerebro-spinal fever, caused by infection with the meningococcus, was epidemic in Great Britain in 1931 and 1932 , some 2,200 cases being notified in each year. The number of cases then declined, and in 1935 and 1936 the annual total was about 900 . Since then there has been again a rise, to 1,500 cases in 1939. In the first seven weeks of this year there were 1,753 cases, and 623 new cases were notified in the week ending March 2. In view of the prevalence of this epidemic, the Ministry of Health has issued a "Memorandum on Cerebro-Spinal Fever" (Memo. 234/Med. H.M. Stationery Office. 2d. net). It discusses the epidemiology of the disease, the control of contacts (who may be carriers of the meningococous) and diagnosis, and describes the treatment and general measures of prevention. Formerly, the administration of anti-meningococcal serum was the only specific treatment, and is still desirable in the very acute cases. Treatment has, however, now been revolutionized by the use of the drugs sulphapyridine and sulphanilamide, and full directions are given as regards dosage and method of administration.

\section{Announcements}

Prof. Walter W. Stewart has been elected to succeed Mr. John D. Rockefeller, jun., who has retired from his position both as chairman and as member of the Board of the Rockefeller Foundation. Prof. Stewart, who is fifty-five, was during 1928-30 an economic adviser to the Bank of England. In 1931 he was appointed American member of the special advisory committee to the Bank for International Settlements. $\mathrm{He}$ is a professor of economics at the Institute for Advanced Study at Princeton University.

THE Ettore Marchiafava Prize, founded by the University of Rome on October 28, 1938, for the best work on morbid anatomy or general pathology, has been awarded to Profs. Mario Monacelli, director of the clinic for dermatology and syphilis at Messina, and Giulio Raffaele, of the University of Rome.

AT the recent annual general meeting of the Institute of Metals, held in London, the following officers were elected: President, Lieut.-Colonel the Hon. R. M. Preston; Vice-Presidents, Dr. S. F. Dorey, Engineer Vice-Admiral Sir George Preece and Mr. A. J. G. Smout; Treasurer, Lieut.-General Sir Ronald Charles ; New Members of Council, Dr. W. E. Alkins, Mr. G. L. Bailey, Captain F. C. Braby, Colonel P. G. J. Gueterbock, and Prof. D. Hanson.

AN after-luncheon lecture will be given at the Chemical Club, 2 Whitehall Court, London, S.W.1, on April 15 by Mr. Arthur Elton, who has taken for his title "The Interpretation of Science by the Film". Mr. Elton is at present at work on the Government scheme, initiated by Sir Kenneth Clark, of propaganda films of a technical nature.

A Congress of Forensic Medicine, Insurance and Criminal Anthropology will be held at Naples during May 30-June 1. Further information can be obtained from the general secretary, Prof. Gennaro Punzo, Via Luciano Armanni 3, Santa Patrizia.

According to a census on June 30, 1939, the total aboriginal population of Australia was 77,269, including 25,712 half-castes. Nearly half the total full-blooded natives were in Western Australia. In New South Wales there were only 794 . 